Supplement of The Cryosphere, 14, 2005-2027, 2020

https://doi.org/10.5194/tc-14-2005-2020-supplement

(C) Author(s) 2020. This work is distributed under

the Creative Commons Attribution 4.0 License.

(c) (1)

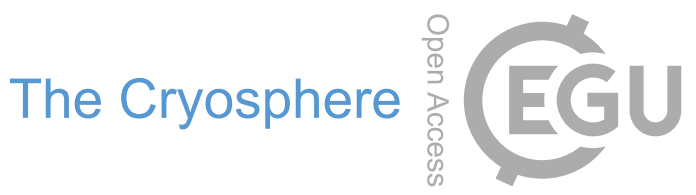

Supplement of

\title{
Glacier runoff variations since 1955 in the Maipo River basin, in the semiarid Andes of central Chile
}

\author{
Álvaro Ayala et al. \\ Correspondence to: Álvaro Ayala (alvaro.ayala@ceaza.cl)
}

The copyright of individual parts of the supplement might differ from the CC BY 4.0 License. 


\section{Section S1: Geodetic mass balances}

This section presents a summary of the methods included in the study by Farías-Barahona et al. (2020):

20 Farías-Barahona, D., Ayala, Á., Bravo, C., Vivero, S., Seehaus, T., Vijay, S., Schaefer, M., Buglio, F., Casassa, G. and Braun, M. H.: 60 years of glacier elevation and mass changes in the Maipo River Basin, central Andes of Chile, Remote Sens., In review, 2020.

\section{Derivation of the 1955 DEM}

A Digital Elevation Model (DEM) of the Chilean Central Andes was derived from a topographic map at a 1:50,000 scale. The 25 map was based upon aerial photographs taken in 1955 (Hycon flights), as part of an agreement between Chile and the InterAmerican Geodetic Survey of the United States. The cartography was produced by the Chilean Military Geographic Institute (IGM) using analogue photogrammetric techniques, which requires an operator that stereoscopically reconstructs the imaging geometry using mechanical or optical devices (Mikhail et al., 2001). The vertical reference used mean sea level corresponding to precise trigonometric levelling with theodolites from tide gauge benchmarks located on the Chilean coast. The maps were 30 georeferenced to the PSAD56 datum, UTM projection zone 19S.

The generation of Digital Elevation Models (DEMs) for 1955 consists of the following steps (Farías-Barahona et al., 2019):

- The 1955 topographic maps containing 50-m contour lines were scanned by the IGM at 1200 DPI.

- The scanned maps were georeferenced to a common base using standard Geographic Information System (GIS) procedures. The original PSAD 56 datum was converted to the WGS84 datum.

35 - The 50-m contour lines were digitized.

- The contour lines were interpolated using the kriging method (e.g. Mölg et al., 2017; Farías-Barahona et al., 2019). A DEM with a final resolution of $30 \mathrm{~m}$ was then generated from the contours (Farías-Barahona et al., 2019).

\section{Derivation of the 2013 DEM}

A DEM of the study area for year 2013 was derived from TanDEM-X as follows:

- A set of TanDEM-X scenes from March 2013 was selected (see Figure S1).

- The TanDEM-X scenes were processed based on differential SAR interferometry.

- The interferograms were filtered and a phase unwrapping procedure was performed using the minimum cost flow algorithm. The data were then converted to differential heights.

A detailed description of the derivation of the TanDEM-X DEM processing can be found in Braun et al. (2019). 


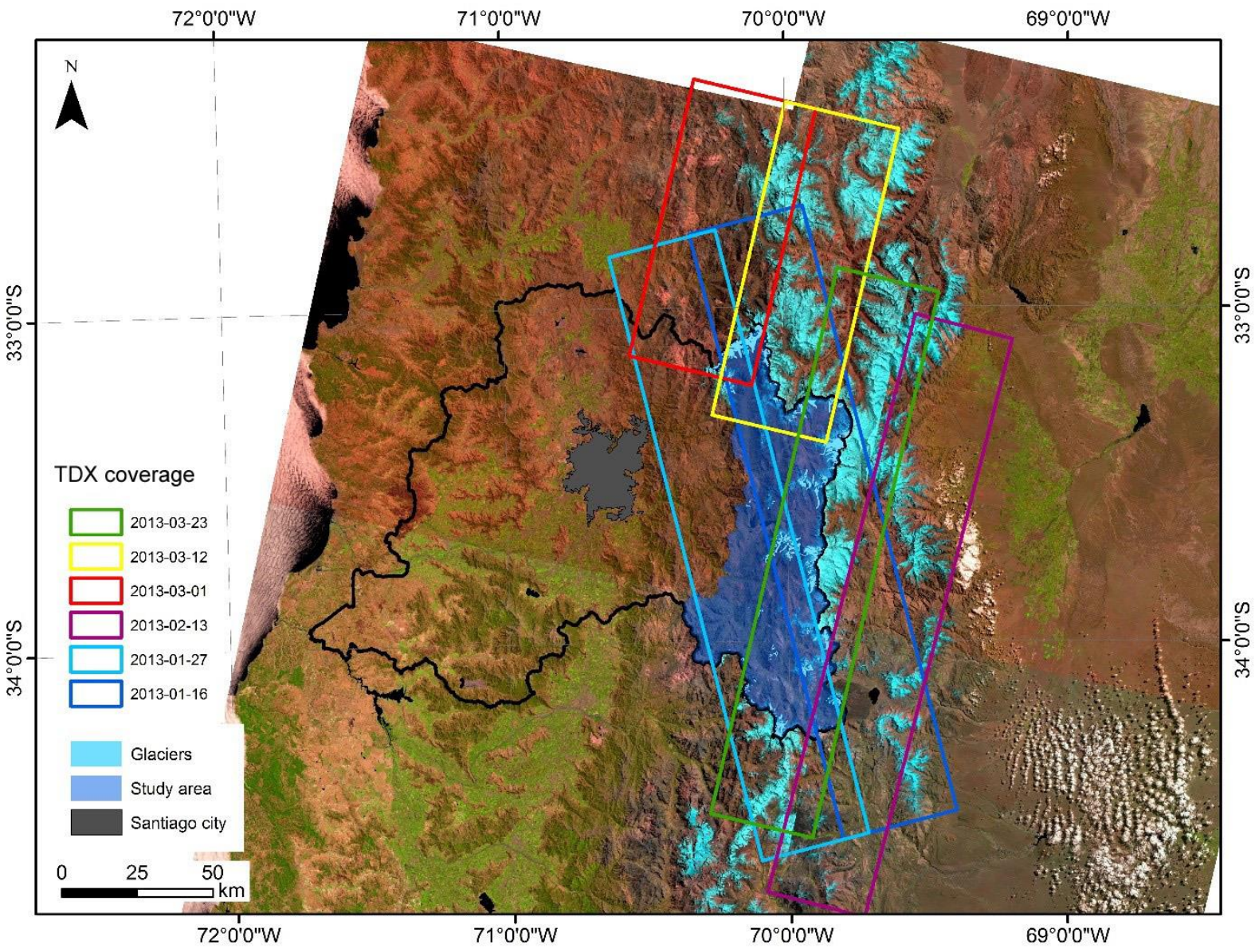

Figure S1. TanDEM-X (TDX) coverage for the Maipo River Basin in 2013. Background image from USGS Landsat 8 satellite data from February 26, 2014.

\section{DEM differencing and uncertainties}

The geodetic mass balances for the periods 1955-2000 and 2000-2013 were derived using DEM differencing with the SRTM

50 DEM. This product was obtained by bi-static radar interferometry that were acquired simultaneously in the C-band and Xband frequencies between the 11th and 22nd of February 2000 (Farr et al., 2007). This date corresponds to the ablation period in the Southern Hemisphere. Using optical satellite imagery, it was checked that melt-favourable conditions dominated over the Central Andes at the time of the SRTM campaign. The DEMs were co-registered (Nuth and Kääb, 2011) using a mask of stable areas with the Shuttle Radar Topography Mission (SRTM-C) as reference.

55 The uncertainty in the geodetic mass balances was explicitly quantified based on standard error propagation methods (Braun et al., 2019). Four sources of uncertainty were recognized: i) volume-to-mass conversion, ii) glacier outlines, iii) radar signal penetration of SRTM, and iv) errors in the DEM differencing. 
Section S2 Additional tables

Table S1: Parameters in TOPKAPI-ETH's sub-surface flux module for the 1955-2016 time period

\begin{tabular}{|c|c|c|c|}
\hline \multirow{3}{*}{ Parameter } & \multicolumn{2}{|c|}{ Calibrated value } & \multirow{3}{*}{ Units } \\
\hline & \multicolumn{2}{|c|}{ Areas of the Maipo River Basin $(*)$} & \\
\hline & $\begin{array}{l}\text { Vegetated } \\
\text { areas }\end{array}$ & $\begin{array}{c}\text { Non-vegetated } \\
\text { areas }\end{array}$ & \\
\hline Depth & 6.5 & 2.1 & ${ }^{\circ} \mathrm{C}$ \\
\hline Depth (lower layer) & 27.6 & 12.2 & $\mathrm{~m}$ \\
\hline Vertical hydraulic conductivity at saturation & 0.074 & 0.045 & $\mathrm{~m} \mathrm{~s}^{-1}$ \\
\hline Vertical hydraulic conductivity at saturation (lower layer) & 0.026 & 0.056 & $\mathrm{~m} \mathrm{~s}^{-1}$ \\
\hline Horizontal hydraulic conductivity at saturation & 0.003 & 0.015 & $\mathrm{~m} \mathrm{~s}^{-1}$ \\
\hline Horizontal hydraulic conductivity at saturation (lower layer) & 0.438 & 0.605 & $\mathrm{~m} \mathrm{~s}^{-1}$ \\
\hline Water content ratio at saturation & 0.65 & 0.66 & - \\
\hline Water content ratio at saturation (lower layer) & 0.66 & 0.31 & - \\
\hline Residual water content ratio & 0.1 & 0.1 & - \\
\hline Residual water content ratio (lower layer) & 0.1 & 0.1 & - \\
\hline Brooks-Corey exponent for the permeability-saturation curve (horizontal) & 3.5 & 3.5 & - \\
\hline $\begin{array}{l}\text { Brooks-Corey exponent for the permeability-saturation curve (horizontal) } \\
\text { (lower layer) }\end{array}$ & 3.5 & 3.5 & - \\
\hline Clapp-Hornberger exponent for the percolation equation (vertical) & 13.0 & 13.0 & - \\
\hline $\begin{array}{c}\text { Clapp-Hornberger exponent for the percolation equation (vertical) (lower } \\
\text { layer) }\end{array}$ & 13.0 & 13.0 & - \\
\hline Soil drainage coefficient. Used for upper and lower soil layers & 1 & 1 & - \\
\hline $\begin{array}{c}\text { Minimum values of soil moisture to have ETA greater zero (ratio } \\
\text { of maximum soil moisture between } 0-1 \text { ) }\end{array}$ & 0.1 & 0.1 & - \\
\hline $\begin{array}{l}\text { Minimum values of soil moisture for ETA to be equal to ETP } \\
\text { (ratio of maximum soil moisture between } 0-1 \text { ) }\end{array}$ & 0.35 & 0.35 & - \\
\hline
\end{tabular}

60 (*): The classification was made based on the land use maps developed by the National Forest Corporation (CONAF) database (https://sit.conaf.cl/). 
Table S2: Summary of the performed simulations

\begin{tabular}{|c|c|c|c|c|c|}
\hline $\begin{array}{l}\text { Name of } \\
\text { simulation }\end{array}$ & Method & $\begin{array}{l}\text { Domain } \\
(*)\end{array}$ & Period & $\begin{array}{l}\text { Scenario } \\
(* *)\end{array}$ & Comments \\
\hline SIM-1A & $\begin{array}{l}\text { TOPKAPI- } \\
\text { ETH }\end{array}$ & $\begin{array}{l}\text { Maipo } \\
\text { River } \\
\text { Basin }\end{array}$ & $\begin{array}{l}1955- \\
2016\end{array}$ & $\begin{array}{l}\text { Observed } \\
\text { climate }\end{array}$ & $\begin{array}{l}\text { The subperiod } 2003-2013 \text { is used for model } \\
\text { calibration. The subperiod } 1984-2002 \text { is used for } \\
\text { model validation. Snow parameters are chosen } \\
\text { based on standard values in the literature. Soil } \\
\text { parameters are automatically calibrated. }\end{array}$ \\
\hline \multirow[t]{2}{*}{ SIM-1B } & $\begin{array}{l}\text { TOPKAPI- } \\
\text { ETH }\end{array}$ & $\begin{array}{l}\text { Selected } \\
\text { glacier } \mathrm{x}\end{array}$ & $\begin{array}{l}1955- \\
2000\end{array}$ & $\begin{array}{l}\text { Observed } \\
\text { climate }\end{array}$ & $\begin{array}{l}\text { Parameters SRF and TF are used to fit the } \\
\text { geodetic mass balance of each glacier. The rest of } \\
\text { the parameters are chosen based on standard } \\
\text { values in the literature. }\end{array}$ \\
\hline & $\begin{array}{l}\text { TOPKAPI- } \\
\text { ETH }\end{array}$ & $\begin{array}{l}\text { Selected } \\
\text { glacier } \mathrm{x}\end{array}$ & $\begin{array}{l}2000- \\
2016\end{array}$ & $\begin{array}{l}\text { Observed } \\
\text { climate }\end{array}$ & $\begin{array}{l}\text { Parameters SRF and TF are used to fit the } \\
\text { geodetic mass balance of each glacier. The rest of } \\
\text { the parameters are chosen based on standard } \\
\text { values in the literature. }\end{array}$ \\
\hline SIM-1C & Extrapolation & $\begin{array}{l}\text { All } \\
\text { glaciers }\end{array}$ & $\begin{array}{l}1955- \\
2016\end{array}$ & $\begin{array}{l}\text { Observed } \\
\text { climate }\end{array}$ & Extrapolation calculated from SIM-1B \\
\hline SIM-2A & $\begin{array}{l}\text { TOPKAPI- } \\
\text { ETH }\end{array}$ & $\begin{array}{l}\text { Maipo } \\
\text { River } \\
\text { Basin }\end{array}$ & $\begin{array}{l}2000- \\
2099\end{array}$ & $\begin{array}{l}\text { Synthetic } \\
\text { scenario y }\end{array}$ & As in SIM-1A \\
\hline SIM-2B & $\begin{array}{l}\text { TOPKAPI- } \\
\text { ETH }\end{array}$ & $\begin{array}{l}\text { Selected } \\
\text { glacier } \mathrm{x}\end{array}$ & $\begin{array}{l}2000- \\
2099\end{array}$ & $\begin{array}{l}\text { Synthetic } \\
\text { scenario y }\end{array}$ & As in SIM-1B \\
\hline SIM-2C & Extrapolation & $\begin{array}{l}\text { All } \\
\text { glaciers }\end{array}$ & $\begin{array}{l}2000- \\
2099\end{array}$ & $\begin{array}{l}\text { Synthetic } \\
\text { scenario y }\end{array}$ & Extrapolation calculated from SIM-2B \\
\hline
\end{tabular}

(*): Selected glaciers $\mathrm{x}$ go from 1 to $26,(* *)$ : Future scenarios y go from 1 to 10 . 
We present additional model validation using two datasets: i) six streamflow gauges at intermediate locations of the main catchment, and ii) SWE direct measurements at the Laguna Negra monitoring site of the DGA. The SWE measurements consist of 50 data points measured in the period 1969-2007. While Figure S2 shows the location of the gauges and Laguna Negra in the Maipo River Basin, figures S3 to S7 and Table S3 show results of the

70 validation.

While our simulations of SWE at Laguna Negra compare well to the observations (Fig. S6-S7), this is not always the case for the streamflow values. This is partly because there are many water diversions that subtract water from the Maipo River and its tributaries, and some of the available streamflow records at intermediate gauges have not been corrected for these water extractions. However, considering that no specific calibration of the sub-surface

75 parameters for the intermediate river sections was performed, results of the model validation are in general satisfactory at both monthly (Tab. S3 and Fig. S3-S4) and daily (Fig. S5) time scales.

Table S3: Results of the model validation at streamflow gauges at the monthly scale

\begin{tabular}{|c|c|c|c|c|c|}
\hline Gauge & $\begin{array}{l}\text { Time } \\
\text { period }\end{array}$ & $\begin{array}{c}\text { Average } \\
\text { streamflow } \\
\left(\mathbf{m}^{3} \mathbf{s}^{-1}\right)\end{array}$ & $\begin{array}{l}\text { Nash- } \\
\text { Sutcliffe } \\
\text { (NS) }\end{array}$ & $\begin{array}{c}\text { Root Mean Square } \\
\text { Error (RMSE) } \\
\left(\mathbf{m}^{3} \mathbf{s}^{-1}\right)\end{array}$ & $\begin{array}{c}\text { Mean Bias } \\
\text { (BIAS) } \\
(\%)\end{array}$ \\
\hline $\begin{array}{c}\text { Río Maipo en Las } \\
\text { Hualtatas }\end{array}$ & $\begin{array}{l}1979- \\
2013\end{array}$ & 32.3 & 0.63 & 15.6 & -11.2 \\
\hline $\begin{array}{c}\text { Río Volcán en } \\
\text { Queltehues }\end{array}$ & $\begin{array}{l}1955- \\
2015\end{array}$ & 8.1 & 0.61 & 6.1 & -22.0 \\
\hline $\begin{array}{c}\text { Río Maipo en San } \\
\text { Alfonso }\end{array}$ & $\begin{array}{l}1955- \\
2015\end{array}$ & 73.0 & 0.60 & 35.8 & -12.2 \\
\hline $\begin{array}{l}\text { Río Colorado antes junta } \\
\text { río Olivares }(*)\end{array}$ & $\begin{array}{l}1978- \\
2016\end{array}$ & 11.3 & 0.49 & 9.9 & -23.9 \\
\hline $\begin{array}{l}\text { Río Olivares antes junta } \\
\text { río Colorado }(*)\end{array}$ & $\begin{array}{l}1978- \\
2016\end{array}$ & 6.0 & 0.26 & 7.0 & -4.8 \\
\hline $\begin{array}{l}\text { Río Colorado antes junta } \\
\text { río Maipo }(*)\end{array}$ & $\begin{array}{l}1955- \\
2015\end{array}$ & 30.3 & 0.26 & 17.4 & +19.6 \\
\hline
\end{tabular}

(*): Available streamflow observations are not corrected for water extractions 


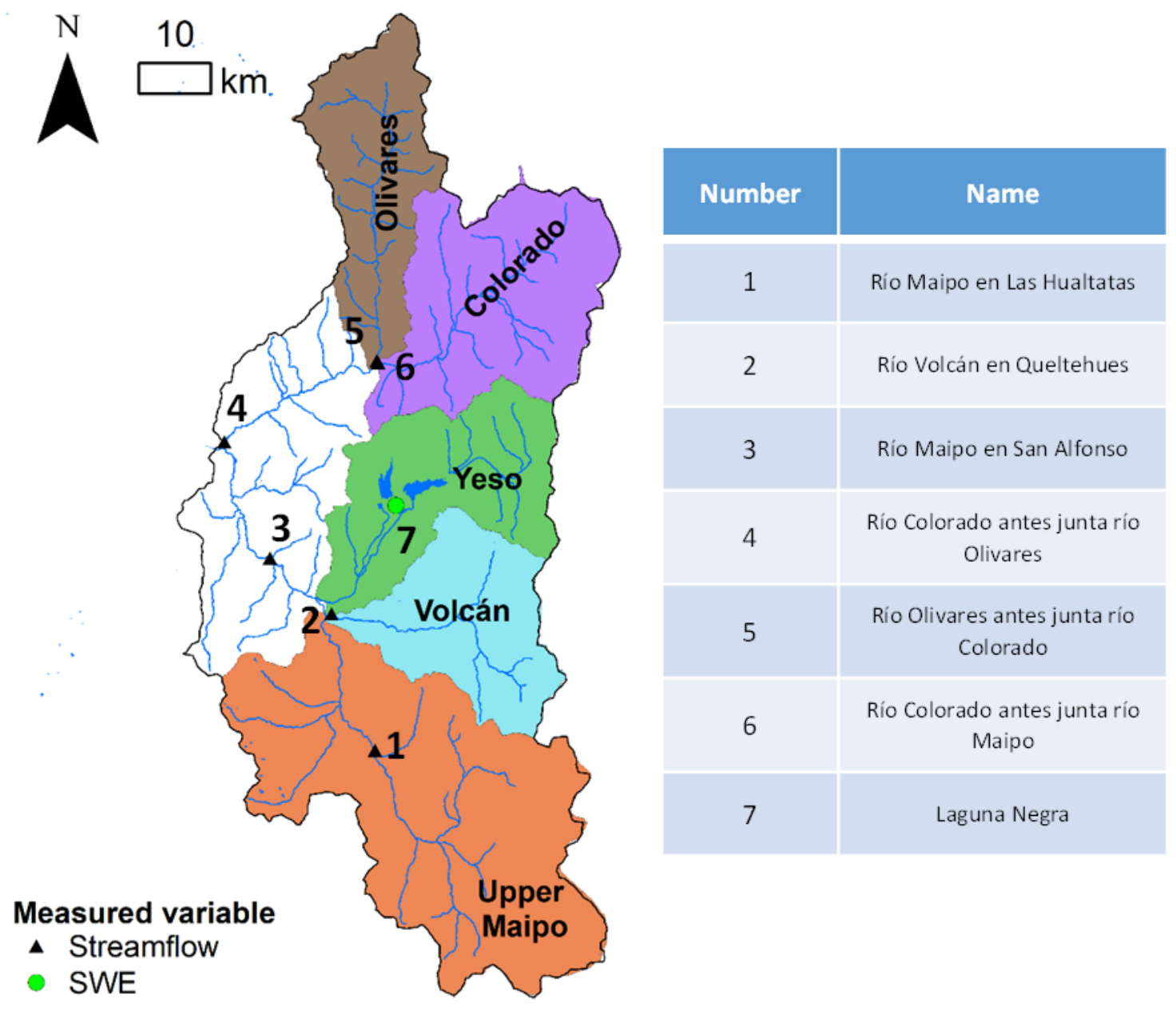

80 Figure S2: Location of intermediate streamflow gauges and the Laguna Negra snow monitoring site. Note that gauges 5 and 6 are closely located. 

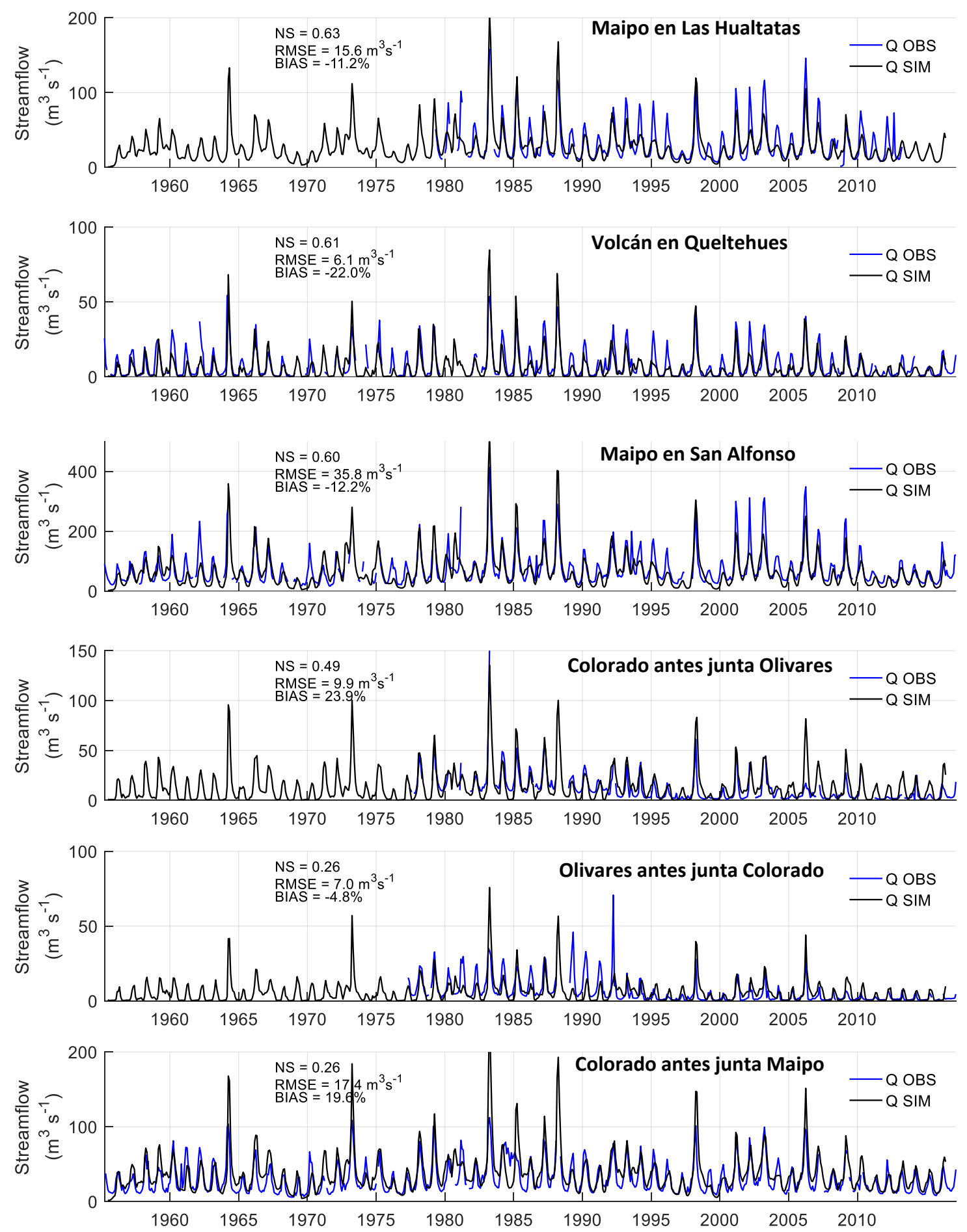

Figure S3: Validation of model results at six intermediate streamflow gauges. Monthly time series. 

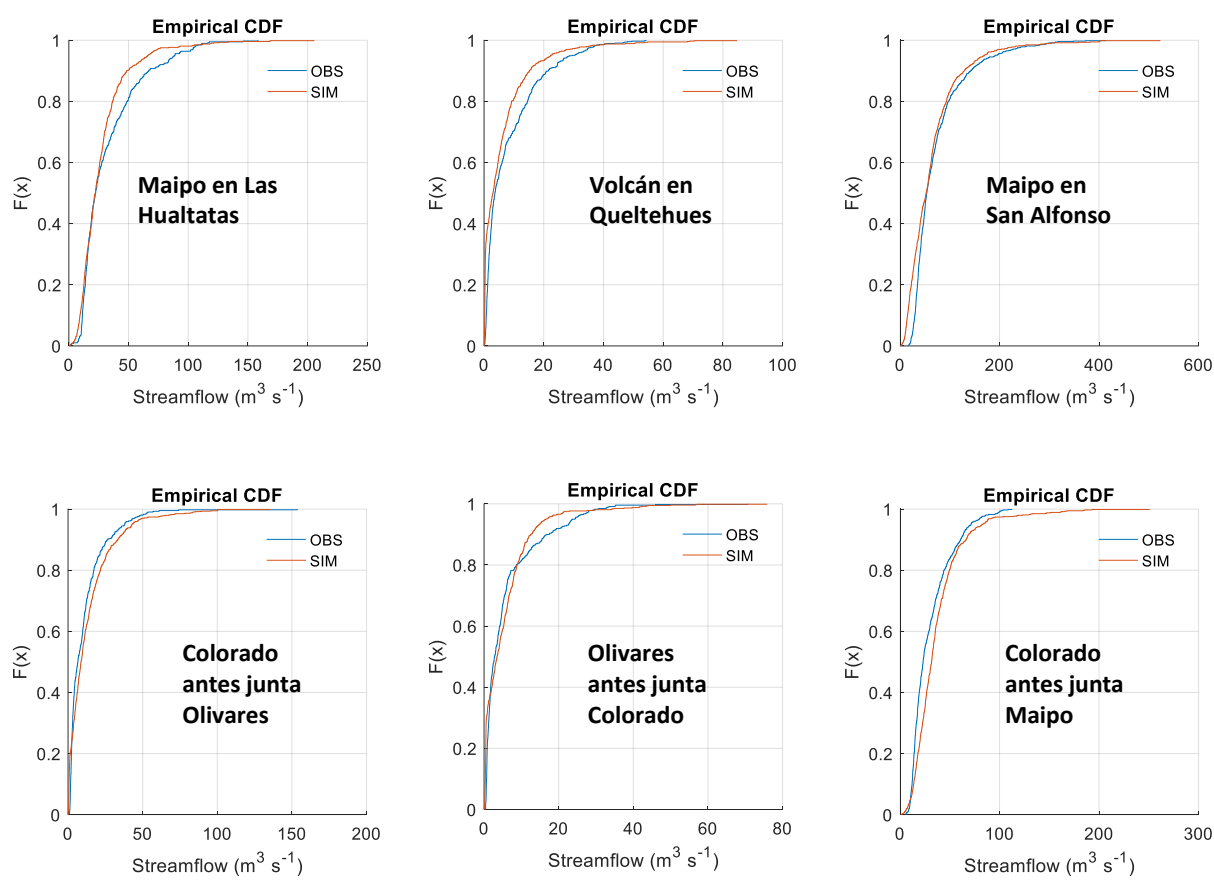

Figure S4: Validation of model results at six intermediate streamflow gauges. Flow-duration curves of monthly time series.
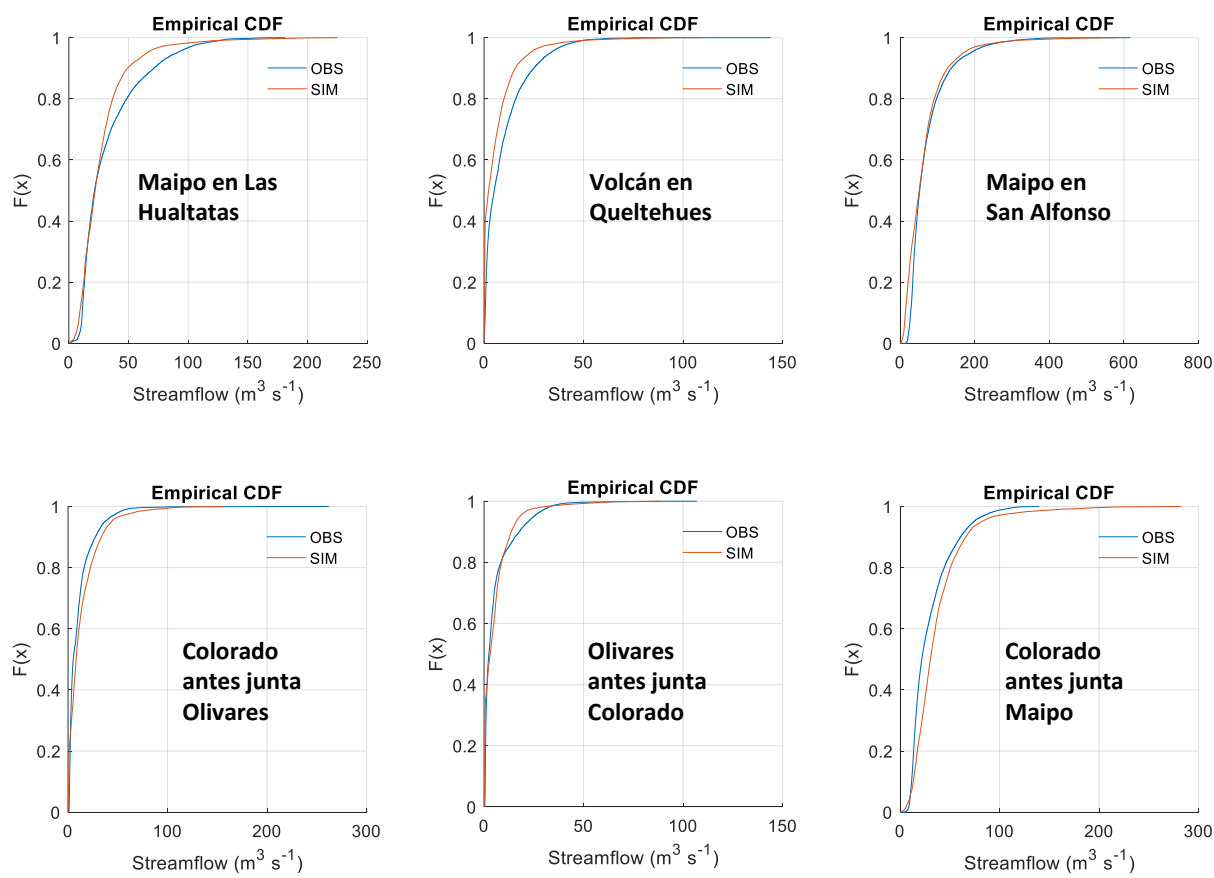

Figure S5: Validation of model results at six intermediate streamflow gauges. Flow-duration curves of daily time series. 


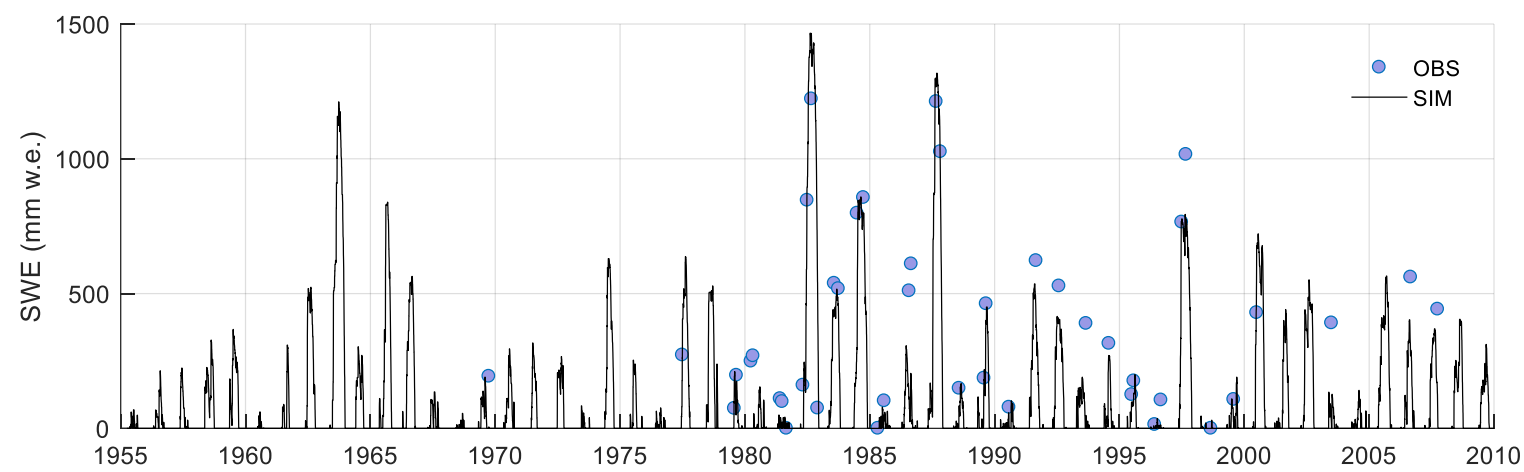

Figure S6: Validation of model results using SWE manual measurements at Laguna Negra $\left(33.67^{\circ} \mathrm{S}, 70.11^{\circ} \mathrm{W}\right)$. The SWE measurements consist of 50 data points measured in the period 1969-2007. Daily time series of simulated values against observations.

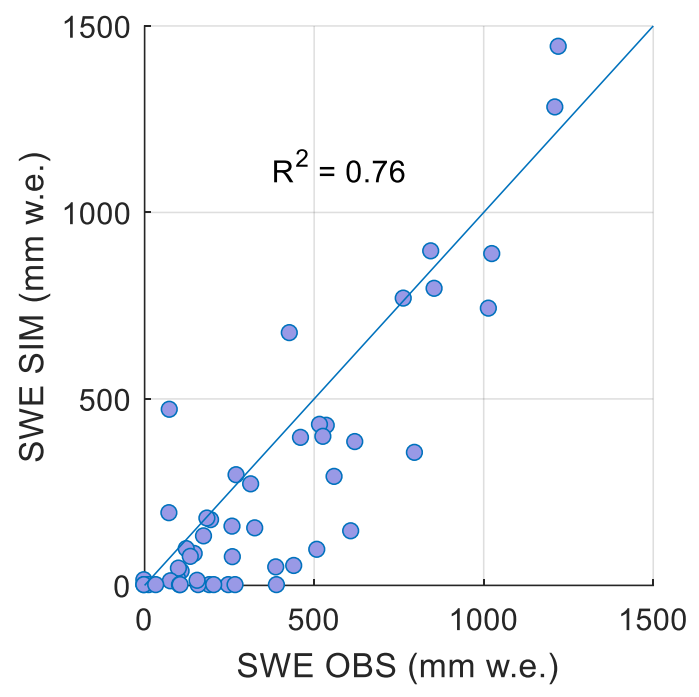

95 Figure S7: Validation of model results using SWE manual measurements at Laguna Negra $\left(33.67^{\circ} \mathrm{S}, 70.11^{\circ} \mathrm{W}\right)$. The SWE measurements consist of 50 data points measured in the period 1969-2007. Scatter plot of observations and simulated values at the time of the measurements. 
100 References

Braun, M. H., Malz, P., Sommer, C., Farías-Barahona, D., Sauter, T., Casassa, G., Soruco, A., Skvarca, P. and Seehaus, T. C.: Constraining glacier elevation and mass changes in South America, Nat. Clim. Chang., 9(2), 130-136, doi:10.1038/s41558018-0375-7, 2019.

Farías-Barahona, D., Vivero, S., Casassa, G., Schaefer, M., Burger, F., Seehaus, T., Iribarren-Anacona, P., Escobar, F. and 105 Braun, M. H.: Geodetic mass balances and area changes of Echaurren Norte Glacier (Central Andes, Chile) between 1955 and 2015, Remote Sens., 11(3), 260, doi:10.3390/rs11030260, 2019.

Farías-Barahona, D., Ayala, Á., Bravo, C., Vivero, S., Seehaus, T., Vijay, S., Schaefer, M., Buglio, F., Casassa, G. and Braun, M. H.: 60 years of glacier elevation and mass changes in the Maipo River Basin, central Andes of Chile, Remote Sens., In review, 2020.

110 Farr, T., Rosen, P., Caro, E., Crippen, R., Duren, R., Hensley, S., Kobrick, M., Paller, M., Rodriguez, E., Roth, L., Seal, D., Shaffer, S., Shimada, J., Umland, J., Werner, M., Oskin, M., Burbank, D. and Alsdorf, D.: The shuttle radar topography mission, Rev. Geophys., 45(2005), 1-33, doi:10.1029/2005RG000183.1.INTRODUCTION, 2007.

Mikhail, E. M., J.S., B. and McGlone, J. C.: Introduction to modern photogrammetry, John Wiley and Sons Inc., New York., 2001.

115 Mölg, N., Ceballos, J. L., Huggel, C., Micheletti, N., Rabatel, A. and Zemp, M.: Ten years of monthly mass balance of conejeras glacier, Colombia, and their evaluation using different interpolation methods, Geogr. Ann. Ser. A Phys. Geogr., 99(2), 155-176, doi:10.1080/04353676.2017.1297678, 2017.

Nuth, C. and Kääb: Co-registration and bias corrections of satellite elevation data sets for quantifying glacier thickness change, Cryosph., 5(1), 271-290, doi:10.5194/tc-5-271-2011, 2011. 